\title{
Establishing and Ranking of Project Dimensions which Influences Risks Management in Construction Projects
}

\author{
Eng. Philemon, Z. Msomba ${ }^{1}$ \\ ${ }^{1}$ Doctoral student, \\ Department of Structural and Construction Engineering, \\ College of Engineering and Technology (COET), \\ University of Dar es salaam, Tanzania
}

\author{
Dr. Matiko Samson ${ }^{2}$ \\ 2 Lecturer, \\ Department of Structural and Construction Engineering, \\ College of Engineering and Technology (COET), \\ University of Dar es Salaam, Tanzania
}

\author{
Dr. Ramadhan, S. Mlinga ${ }^{3}$ \\ 3 Lecturer, \\ Department of Structural and Construction Engineering, \\ College of Engineering and Technology (COET), \\ University of Dar es Salaam, Tanzania
}

\begin{abstract}
Reference to the project dimensions which influences risk management processes is widespread within project management literature. However, certain project dimensions provide a basis for determining the appropriate managerial actions required to complete a project successfully. Six critical project dimensions (CPDs) were identified through a literature review, and confirmed by interviews and pilot studies with professionals in construction industry. A questionnaire instrument containing these six CPDs was distributed to construction project professionals during infrastructure stakeholders meeting held on October, 2016 in Dodoma-Tanzania and 71 completed questionnaires were usable. The Respondents to the questionnaire survey included 33 Clients, 21 Contractors, and 17 Consultants. In order for key project participants to manage risks in construction projects, respondents were requested to rate the project dimensions which influences risk management. The CPDs include project funding, project characteristics, project team, project implementation boundaries, project delivery arrangements, and project stakeholders.
\end{abstract}

Key words: Project Dimensions, Risk Management, Construction Projects

\subsection{INTRODUCTION}

Risk in construction has been the object of attention because of time and cost overruns associated with construction projects (Kartam and Kartam, 2001). It is axiomatic of construction management that a project may be regarded as successful if the project is completed as scheduled, within budget and quality standards as well as achieving a high level of client satisfaction. The construction industry and its parties are associated with high degree of risk due to the nature of construction project dimensions. Increasingly, the fulfillment of these criteria has been associated with the risk management processes influenced by project dimensions. The understanding of the influences of projects dimensions on risk management can shape the success of the project. The aim of this paper is to present the survey findings on influences and ranking of the project dimensions on risk management processes in construction projects.

\subsection{Literature Review}

Taking into account the increasing size and complexity of construction projects, significant fragmentation and involvement of several stakeholders, globalization, fast-paced project lifecycle, and major risk variables caused by these project dimension factors, management of construction projects faces significant challenges. Related researches on project dimensions included Babalola and Ojo (2010), Ruben and Ger (2008), Chan et al, (2004), Hwang et al (2009), Chan et al. (2001), and Cho et al. (2009). Chang and Ibbs (2006) identified factors affecting engineering productivity, including phase involvement, project size, project type, project uncertainty and unclear scope, and quality management. Song et al. (2003) identified 17 project-level factors for steel drafting productivity, including project type, contract type, and piece cloning. Bloch et al. 2012) reports that unclear objectives, lack of business focus, shifting requirements, technical complexity, unaligned team, lack of skill, unrealistic schedule and reactive planning are the failure factors of software projects. Ruben and Ger (2008) examined and ranked project dimensions to be used in choosing procurement method type for future projects. He examined 42 dimensions identified by previous authors (Baccarini, 1996; Tukel and Rom, 1998; Chua et al., 1999; Dissanayaka and Kumarawamy, 1999 and Ling, 2004)) and determined the most important ones. His finding showed that project complexity was the most important one which suggested that complexity of a project should be appropriately assessed in relation to the procurement method in use. In the context of an increasing uncertainty, project complexity that leads to nonlinear and unpredictable outcomes (Maylor et al., 2008), the traditional project management methods, which are underpinned by the deterministic model, focusing on planning 
and control, have shown their limitations (Winter et al. 2006).Therefore, the classic triangle of parameters time, cost and quality are no longer sufficient to reflect the reality of projects, failing to grasp their complex and dynamic nature (Jaafari 2003; Vidal and Marle, 2008). Cho et al. (2009) studied 17 project dimensions and identified those that affected the level of project performance through structural equation model. Effective management of these large projects is a new and unique challenge which requires the use of project management and control methods that have not been used extensively in the past (Sumner, 2000). The traditional approach is open to challenge, a paradigm shift in project management is essential for it to be relevant and effective in a complex society of this century (Jaafari, 2003).

Various project dimensions were investigated by these researchers; however, this paper focused on six critical project dimensions which may influence project risk management processes and these are project characteristics (complexity, uncertainty, type, size and site), project team (clients, contractors and consultants), Project funding (financier, disbursement and mode of payment), project implementation boundaries (scope, budget, duration and quality), stakeholders involvement (customers, users and Regulators) and procurement implementation arrangement (procurement, delivery method and contract strategy).

\subsection{METHODOLOGY}

The research methodology comprised a comprehensive literature review, a questionnaire survey. Questionnaire survey was employed to get professionals opinions on critical project dimensions which influences risk management processes in construction projects. Questionnaires were designed in a way that, the level of influences of critical project dimensions on effective project risk management processes. Opinions of respondents were set in five categories namely; critical, important, somehow important, less important and not important. Respondents, were asked to provide their opinions by ticking a column to indicate the level of influences of project dimensions, on a Likert scale to facilitate data analysis in term $5=$ critical, $4=$ important, $3=$ somehow important, $2=$ less important and 1= not important. 120 Questionnaire were distributed to construction project professionals during infrastructures stakeholders meeting held on October, 2016 in Dodoma-Tanzania and 71 completed questionnaires were usable.

\subsection{Data Analysis}

The rating and ranking of critical project dimensions influencing risk management processes was carried out based on their mean values. In selecting the critical project dimension the cut-off mean value is 2.50 and above, which represents significant. The data collected from the questionnaire were analyzed with the assistance of Statistical Package for Social Science (SPSS) version10.0. The survey responses were analysed using the multi-attribute method (Mbachu, 2011). This involved computing the mean rating of all responses to a particular project dimension. Respondents were asked to rate each project dimension on a five-point Likert rating scale; rating point 5 being highest rating for most important factors and rating point 1 being for factors that were perceived to be 'not at all important'. The mean $(\mathrm{M})$ that represents the average of the responses for a particular enabling factor was computed using the expression below

$$
M=\left(\sum_{i=1}^{5} W i+f i\right) \frac{x 100}{n} \%
$$

Where:

$M=$ this is computed as summation of importance rating (i.e. the mean $(\mathrm{M})$ representative rating assigned to a specific critical project dimension by all the respondents) $w i=$ rating point, ranging from $(1$ to 5$)$

$f i=$ frequency of response; i.e. number of responses associating a critical project dimension with a particular rating point

$n=$ total number of respondents rating a particular critical enabling factor in the survey

\subsection{Measuring respondents' level of agreement}

Coefficient of variation (COV) indicates the standard deviation as a percentage of the mean. It is useful in comparing relative variability of different responses. It could therefore be an indicator of the level of validity and reliability of the research design, measuring instrument and findings (Elhag et al., 2005). The following expression was used to compute the COV.

$$
\operatorname{cov}=\frac{S}{X} X 100 \%
$$

Where:

$\mathrm{COV}=$ Coefficient of variation,

$\mathrm{S}=$ Standard deviation

$\mathrm{X}=$ Weighted mean of sample

\subsection{General Analysis of Respondents}

A total of 120 questionnaires were distributed out of which 76 were completed and returned which represents 63 per cent return rate. However, only 71 questionnaires were fully usable. The remaining 5 were partial, incomplete or incorrectly filled and therefore, excluded from the analysis. All 71 respondents had at least a Bachelor degree in Engineering, Architecture or Quantity surveying and had at least 5 years experience in construction industry. This kind of qualification and experience is considered adequate to enable respondents to give credible responses. $46.5 \%$ of respondents were clients, $29.6 \%$ contractors and $23.9 \%$ were consultants.

\subsection{RANKING OF CRITICAL PROJECT DIMENSIONS (CPDs)}

The rating and ranking of critical project dimensions which influences risk management processes in construction project was carried out based on their mean values. In selecting the critical project dimension the cut-off mean value is 2.50 and above, which represents significant. The results of this part of study provide an indication of the mean rating and ranking of critical project dimensions affecting the effective project risk management in construction projects. Table 2 show summaries of project dimensions rating and ranking according to each type of categories of construction participants and overall ranking as perceived by the respondents. Also the table 
indicates the coefficient of variation (COV) which is useful in comparing relative variability of different responses.

The results in Table 2 indicate the rating and ranking of critical project dimensions from different category of construction stakeholders. The overall ranking of these project dimensions perceived to affect project risk management processes in construction projects in descending order are: project funding, project characteristics, project team, project implementation boundaries, procurement implementation arrangement and stakeholders involvement. Also Table 1 indicates the value COV which range from $14.8 \%$ to $19.00 \%$ which reflect the convergence of opinions among the participants in their ratings. A lower number of COV means higher agreement between all participants.

\begin{tabular}{|c|c|c|c|c|}
\hline \multirow{2}{*}{ 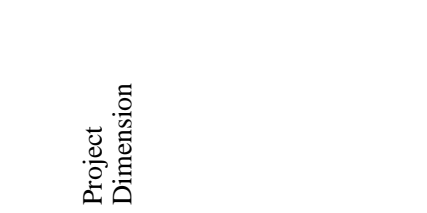 } & \multicolumn{2}{|c|}{ 过 } & \multicolumn{2}{|c|}{$\underset{\circlearrowright}{\stackrel{\Xi}{\Xi}}$} \\
\hline & $\sum_{\Sigma}^{\Xi}$ & 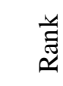 & 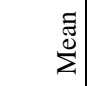 & 艺 \\
\hline \multicolumn{5}{|l|}{ Project funding } \\
\hline $\begin{array}{l}\text { (Financier, disbursement, mode of } \\
\text { payment, adequacy) }\end{array}$ & 4.52 & 1 & 4.57 & 1 \\
\hline \multicolumn{5}{|l|}{ Project characteristics } \\
\hline $\begin{array}{c}\text { (Complexity, uncertainty, type, size, } \\
\text { location) }\end{array}$ & 4.46 & 2 & 4.14 & 2 \\
\hline \multicolumn{5}{|l|}{ Project team } \\
\hline (Clients, Contractors, Consultants) & 3.97 & 4 & 3.91 & 3 \\
\hline \multicolumn{5}{|l|}{ Project implementation boundaries } \\
\hline (Scope, Budget, Duration, Quality) & 4.33 & 3 & 3.71 & 5 \\
\hline \multicolumn{5}{|l|}{$\begin{array}{c}\text { Procurement implementation } \\
\text { arrangement }\end{array}$} \\
\hline $\begin{array}{c}\text { (Procurement, delivery method } \\
\text { Contract strategy) }\end{array}$ & 3.88 & 5 & 3.80 & 4 \\
\hline \multicolumn{5}{|l|}{ Stakeholders involvement } \\
\hline (Customers, Users, Regulator) & 3.82 & 6 & 3.43 & 6 \\
\hline
\end{tabular}

\begin{tabular}{|c|c|c|c|c|c|}
\hline \multirow{2}{*}{ 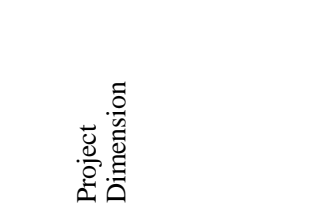 } & \multicolumn{2}{|c|}{$\begin{array}{l}\overline{\vec{a}} \\
\overline{0} \\
\overline{0}\end{array}$} & \multirow{2}{*}{$\begin{array}{l}\delta^{\circ} \\
\partial \\
0\end{array}$} & \multicolumn{2}{|c|}{ 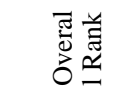 } \\
\hline & 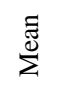 & 范 & & $\sum^{\frac{\varpi}{\Sigma}}$ & 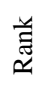 \\
\hline \multicolumn{6}{|l|}{ Project funding } \\
\hline $\begin{array}{l}\text { (Financier, disbursement, } \\
\text { mode of payment, adequacy) }\end{array}$ & 4.71 & 1 & 14.8 & 4.38 & 1 \\
\hline \multicolumn{6}{|l|}{ Project characteristics } \\
\hline $\begin{array}{c}\text { (Complexity, uncertainty, } \\
\text { type, size, location) }\end{array}$ & 4.18 & 3 & 16.0 & 4.37 & 2 \\
\hline \multicolumn{6}{|l|}{ Project team } \\
\hline $\begin{array}{c}\text { (Clients, Contractors, } \\
\text { Consultants) }\end{array}$ & 4.59 & 2 & 16.90 & 4.35 & 3 \\
\hline \multicolumn{6}{|l|}{$\begin{array}{c}\text { Project implementation } \\
\text { boundaries }\end{array}$} \\
\hline $\begin{array}{c}\text { (Scope, Budget, Duration, } \\
\text { Quality) }\end{array}$ & 4.06 & 4 & 18.20 & $\begin{array}{l}4 . \\
25\end{array}$ & 4 \\
\hline \multicolumn{6}{|l|}{$\begin{array}{c}\text { Procurement implementation } \\
\text { arrangement }\end{array}$} \\
\hline $\begin{array}{c}\text { (Procurement, delivery } \\
\text { method Contract strategy) }\end{array}$ & 3.94 & 5 & 17.50 & 4.19 & 5 \\
\hline \multicolumn{6}{|l|}{ Stakeholders involvement } \\
\hline $\begin{array}{l}\text { (Customers, Users, } \\
\text { Regulator) }\end{array}$ & 3.59 & 6 & 19.00 & 4.03 & 6 \\
\hline
\end{tabular}

4.1 Project funding
Project funding dimension was perceived to be the most important project dimensions affecting the effective project risk management processes in construction projects. The dimension is ranked in the first position by all groups of project participants with mean rating equal to 4.52 for clients, 4.57 for contractors, and 4.71 for consultants and 4.38 for the overall ranking with $\mathrm{COV}$ value equal to $14.8 \%$. This agreement between all categories of construction groups is traced back to the difficult on project funding situation from which construction projects suffers. Construction projects in Tanzania are suffering from a number of problems (time overruns, cost overruns, claims and disputes) because of poor arrangement of project funding especially projects funded by the Government of Tanzania. These problems can be considered as an obstacle for effective project risk management. All clients, contractors and consultants feel with such this sensitive problem in their projects. This affects implementation of scheduled activities contained in the annual work plan of the project. Late payment of suppliers due to non-availability of funds results in penalties in form of cost overruns charged on the project thereby increasing the overall cost of the project. Further, due to implementation delays, the projects are never completed on time thereby occasioning requests for extension of implementation time. This finding is in line with the study of Toor and Ogunlana (2008) that identified a group of factors - cash flow, difficulty in receiving payment, monthly payment difficulties, difficulty in financing project by contractors, cash flow during construction - that contribute to delays in major construction projects.

\subsection{Project characteristics}

The dimension has been ranked the second in the overall ranking with mean equal to 4.37 and $\mathrm{COV}$ value equal to $16.0 \%$. It has been ranked by the clients respondents in the second position with mean equal to 4.6. The dimension has been ranked by the contractors' respondents in the third position with mean equal 4.14 and also has been ranked by the consultants' respondents in the second position with mean equal 4.59. This project dimension can be considered as an important for all three categories of construction groups and it has almost similar rating for all parties as it affects directly on effective project risk management and project performance as whole. Project characteristics influence project team performance to the extent that a project may require specialised skills or specialised plant and equipment. Where these are unavailable, the effect on project delivery may be increased duration and cost, and compromised quality. Therefore an understanding of project characteristics and how they might be managed is of significant importance. For example the characteristics of a complex project would include difficulty, uncertainty, and uniqueness, indirect communication among project stakeholders, dynamism, and lack of clarity on the goals of the project. Also complex projects have a high degree of disorder and instability and they are sensitive to small changes and are typically dynamic in nature.

\subsection{Project team}

The dimension has been ranked in third position in overall ranking with mean value equal to 4.35 and $\mathrm{COV}$ value equal 
to $16.90 \%$. It has been ranked in the fourth position by client respondents with mean equal to 3.97. Also it has been ranked in third position by consultants respondents with men equal to 4.18 and in third position by contractors' respondents with mean equal to 3.91. The capabilities of project team in management of project risks is very important for the success of the project as supported by Walker (1996) how argued that the capabilities of the construction management team in planning, building and communication were found to have a strong positive relationship with construction time performance.

\subsection{Project implementation boundaries}

We all know that projects are considered successful only when they are completed within the boundaries of scope, time, cost and quality. The dimension has been ranked in the fourth position by all respondents with mean equal to 4.25 with $\mathrm{COV}$ value equal to $18.20 \%$. It has been ranked in the third position by client respondents with mean equal to 4.33 . It has been ranked in fourth position by both contractors and consultants' respondents with mean equal to 3.88 and 4.06 respectively. Projects do get completed and closed but not necessarily are considered successful due to cost or schedule overruns which are the most common causes for project failure. Therefore, it is imperative that project participants employ better ideas and novel methodologies and frameworks in managing project boundaries for the success of the projects.

\subsection{Procurement implementation arrangement}

The dimension has been ranked in fifth position in overall ranking with mean value equal to 3.90 and $\mathrm{COV}$ value equal to $17.5 \%$. It has been ranked in the fifth positions by all groups of respondents (clients, contractors and consultants) with mean rating equal to $3.88 ; 3.94$ and 3.71 respectively. Procurement routes have a fundamental impact on performance to the construction project. This finding is supported by Latham (1994) who state that certain routes, such as the traditional procurement systems, promote segregation and antagonism with participants working, in some cases against each other, to avoid losses. The appropriate contracting method and the contract documents for any construction project depend on the nature of the project, but an appropriate contracting method coupled with clear and equitable contract documents do not by themselves ensure project success where people work together in the face of uncertainty and complexity with diverse interests and conflicting agendas. The attitudes of the contracting parties and the co-operative relationships among the project participants are important for successful project delivery. This findings is in line with that of Al-Bahar and Crandall (1990) who point out that, the establishments of a procurement strategy that identifies and prioritises key project objectives as well as reflects aspects of risk, and establishes how the process will be managed are keys to a successful project outcome.

Recognizing the inherent problems caused by the traditional procurement systems and their adverse effect on the project, methods other than the traditional design-bid-build hierarchy have been attempted with some success. Design-build eliminates adversarial situation, resulting in one project entity responsible for design and construction, hopefully forcing communication and collaboration between and among disciplines within that project entity. Construction manager at risk projects typically employ a general contractor in the defined role of construction manager before the design is completed in order to contribute constructability, scheduling and estimating expertise. Integrated Project Delivery, or "IPD", attempts to address the silo issue, but more specifically the issue of the individual party interest trumping that of the project, by addressing the very culture of project relationships. While there are various IPD structures that affect the relationships of project parties, all IPD projects have the same general goals: investment of all major project players in the success or failure of the project; agreed defined project goals; transparent communications and data sharing between or among all significant project participants; and meaningful collaboration among disciplines and project entities.

\subsection{Stakeholders involvement}

Although it is ranked in the last position from the identified project dimensions it still has potential influence in project risk management this is due to the fact that, the early involvement and effective engagement of key stakeholders in project planning makes a significant improvement in the mitigation of possible difficulties and risks. It also generates valuable team spirit, collaborative understanding and common objectives, thus contributing to successful project delivery. This finding is supported by Takim (2009) how argued that, the complex interaction and interrelationships that take place among the parties involved in a construction project determine the overall successful completion of the project. Furthermore, these findings are in line with Cleland (1999) who argue that the project success has been linked to the effective continuous engagement/management of all the project's stakeholders. Encompassing risks and stakeholder management within one process, although relatively complex and time consuming, proves to be a more practical approach to addressing critical issues in projects.

Due to the various and divergent stakeholders' interests in a typical construction project arising from the fragmented and complex nature of construction it is important to identify and assess stakeholders' areas of interests. Communication is a basic ingredient needed to maintain the support, commitment and loyalty of the project stakeholders. It is important for a project management team to manage their differing demands through good communication in the early stages of a project once the stakeholders have been identified (Olander and landin, 2008, Yang et al., 2009). This could provide potentially significant opportunities for eliminating several problems that could prevent the achievement of project success as well as averting or reducing the effect of stakeholder interests' related conflicts which is likely to be more costly if allowed to occur when the project is already underway. Communication is so important that it will require communicating to the stakeholders both beneficial and detrimental effects of the proposed project and associated actions and progress being made as the project get underway (Jergeas et al., 2000). The use of different appropriate means of communication for stakeholders or groups of stakeholders is very important (Chinyio and Akintoye, 2008). Stakeholders could be communicated as deemed appropriate through the 
media, project website, newsletters, signpost/flyers and public engagement.

\section{CONCLUSION}

This paper examined the influence of project dimensions on the risk management processes in the course of implementation of construction projects. The dissection of the six project dimensions identifies thirteen important project elements which shape these dimensions. The elements are complexity, type, size, characteristic of key project participants, procurement, delivery method, contract strategy. Project goals, project funding, project life span, project site, technological advancement, uncertainty, stakeholders' involvement and regulatory mechanism. The result suggests that in order for projects to be successful, all the thirteen project elements need comprehensive evaluation at early stage and throughout the project life cycle.

\section{REFERENCES}

[1] Al-Bahar, J. and Crandall, K.C. (1990), Systematic risk management approach for construction projects, Journal of Construction Engineering Management, Vol. 116, pp. 533-546

[2] Babalola M.O and Ojo, G. K..(2010). Risk and Uncertainties in construction Clients' Cash Flow Forecast, West Africa Built Environment, Res. (WABER) Conference, School of Construction Management and Engineering, Reading University, UK, pp. 469-476

[3] Baccarini, D. (1996). The concept of project complexity- a review, International Journal of Project Management, Vol.14, No. 4, pp. 201-204

[4] Bloch, M., Blumberg and Laartz, J.,(2012). Delivering largescale IT projects on time, on budget, and on value. McKinesey Quarterly pp. October1-6

[5] Chan, A.P. C., Ho, D. C.K and Tam, C. M., (2001), Design and Build project success factors; Multivariate analysis, Journal of Construction Engineering Management, Vol. 127. No2, pp.93100

[6] Chan, A.P. C., Scott, D., and Chan P.C.,(2004). Factor affecting the Success of a Construction Project, Journal of Construction Engineering and Management Vol.130, No, Pp.153-155

[7] Chang, A. S, and Ibbs, W.,(2006). System model for analyzing design productivity, Journal of Management and Engineering Vol. 22, No.1, pp27-34

[8] Chinyio, E.A. and Akintoye, A. (2008), "Practical approaches for engaging stakeholders: findings from the UK." Construction Management and Economics, Vol. 26, No. 6, pp. 591-599

[9] Cho K, Hong T, Hyun, C. (2009), Effect of project characteristics on project performance in construction projects based on structural equation model, International Journal Expert Systems with Appl, Vol. 36, No.7, September, Tarrytown, NY, USA

[10] Chua, D. K. H, Kog, Y.C, Loh, P. K (1999), Critical Success Factors for Different Project Objectives, Journal of Construction Engineering and Management, Vol. 123, No. 3, pp. 142-150

[11] Cleden, D., (2009). Managing project uncertainty, Abingdon: Ashgate Publishing Group

[12] Dissanayaka S. M, Kumaraswamy M. M (1999), comparing contributors to time and cost performance in building projects, Building and Environment, Vol. 34, pp.31-42

[13] Elhag, T., Boussabinaine A., and Ballal T.,(2005). "Critical determinants of construction tendering costs": Quantity surveyorse standpoint", International Journal of Project Management, Vol. 23, No. 7, pp. 538-545.

[14] Hwang, B.G., Thomas, S.T, Haas, C.T, and Caldas, C.H., (2009). Measuring the Impact of Rework on construction Cost Performance, Journal of construction Engineering and ManagementVol.135, No.3, pp.187-198
[15] Jaafari, A. (2003), Project management in the Age of Chaos: A study of professionalism in $21^{\text {st }}$ Century. Proceedings, $17^{\text {th }}$ IPMA World Congress on Project Management (project Oriented Business and Society). Moscow, Russia. 7 pages

[16] Jergeas, G.F., Williamson, E., Skulmoski, G.J., and Thomas, J. L., (2000). Stakeholder management on Construction Projects, AACE International Transaction, pp 12.1-12.5

[17] Kartam, N., Kartam, S., (2001), Risk and its management in the Kuwaiti construction industry: a contractors' perspective. International Journal of Project Management Vol.19, No. 6, pp. 325-335.

[18] Latham, M. (1994), Constructing the team, Final report of the government/industry review of procurement and contractual arrangements in the United Kingdom construction industry, London, HMSO, Department of Environment

[19] Ling F. Y.Y. (2004), Key Determinants of Performance of Design-Bid-Build Projects in Singapore, Building Research and Information, Vol. 32, No. 2,March-April, pp.128-139

[20] Mbachu, J. (2011), Sources of contractor's payment risks and cash flow problems in the New Zealand construction industry: Project team's perceptions of the risks and mitigation measures. Construction Management and Economics, Vol. 29, No. 10, pp. 1027-1041

[21] Maylor, H., Vidgen, R., and Carver, S. (2008), Managerial Complexity in Project- Based Operations: A Grounded Model and Its Implications for Practice. Project Management Journal, Vol. 39, pp.15-26

[22] Olander, S. and Landin, A. (2008) A comparative study of factors affecting the external stakeholder management process. Construction Management and Economics, Vol. 26, No.6, pp. 553-561

[23] Ruben F, and Ger, M.,(2008). Ranking construction project characteristics, in CIB Transformation through construction, $\mathrm{K}$. Carter, S. Ogunlana and A. Kaka eds., pp.1-8, available at $\mathrm{http} / / /$ rubenfavie.com/media/1669/cib2008_ranking\%20construc tion\%20project\%20characteristics. Accessed on 8th Dec 2014

[24] Song, L., Allouche, M., and Abourizk, S. (2003).“ Measuring and estimating steel drafting productivity." ASCE, Honolulu, pp.67-75

[25] Sumner, M.,(2000). "Risk Factors in Enterprise-wide/ERP projects", Journal of Information Technology, Vol.15, pp.317327

[26] Takim, R. (2009). The Management of Stakeholders' Needs and Expectations in the Development of Construction Projects in Malaysia, Modern Applied Science, vol. 3 No. 5 pp 167-175, www.ccsenet.org/journal.html, available 17/11/2014

[27] Toor, Shamas-Ur-Rehman, and Stephen O. Ogunlana.,(2008). "Problems causing delays in major construction projects in Thailand" Construction Management and Economics Vol. 26, No.4: pp. 395-408

[28] Tukel O.I and Rom, W.O (1998), Analysis of the Characteristics of Projects in Diverse Industries, Journal of Operations Management, Vol.16, pp. 43-61

[29] Vidal, L.A., and Marle, F. (2008), Understanding project complexity: implications on project management, Kybernetes, Vol. 37, No.8, pp.1094-1110

[30] Walker, D. H. T. (1996). 'The contribution of the construction management team to good construction time performance: An Australian experience.' Journal of Construction Procurement, Vol., 2 No. 2, pp. 4-18

[31] Winter, M., Smith, C., Morris, P.W.G. and Cicmil, S. (2006), Directions for future research in project management: the main findings of the EPSRC Research Network. International Journal of Project Management, Vol. 24

[32] Yang, J., Shen, Q.P., Ho, M.F., Drew, S.D., Chan, A.P.C.,(2009). Exploring critical success factors for stakeholder management in construction projects, Journal of Civil Engineering and Management Vol.15, No.4, pp.337-348

[33] G. Eason, B. Noble, and I.N. Sneddon, "On certain integrals of Lipschitz-Hankel type involving products of Bessel functions," Phil. Trans. Roy. Soc. London, vol. A247, pp. 529-551, April 1955. (references) 
[34] J. Clerk Maxwell, A Treatise on Electricity and Magnetism, 3rd ed., vol. 2. Oxford: Clarendon, 1892, pp.68-73.

[35] I.S. Jacobs and C.P. Bean, "Fine particles, thin films and exchange anisotropy," in Magnetism, vol. III, G.T. Rado and H. Suhl, Eds. New York: Academic, 1963, pp. 271-350.

[36] K. Elissa, "Title of paper if known," unpublished.

[37] R. Nicole, "Title of paper with only first word capitalized," J. Name Stand. Abbrev., in press.
[38] Y. Yorozu, M. Hirano, K. Oka, and Y. Tagawa, "Electron spectroscopy studies on magneto-optical media and plastic substrate interface," IEEE Transl. J. Magn. Japan, vol. 2, pp. 740-741, August 1987 [Digests 9th Annual Conf. Magnetics Japan, p. 301, 1982].

[39] M. Young, The Technical Writer's Handbook. Mill Valley, CA: University Science, 1989. 